\title{
Prognosis of patients with acute myocardial infarction admitted to a coronary care unit II: Survival after hospital discharge
}

\author{
A. H. KITCHIN AND S. J. POCOCK \\ From the Department of Medicine, University of Edinburgh, Western General Hospital; and \\ Medical Computing and Statistics Group, Edinburgh University Medical School
}

The factors adversely affecting long-term prognosis differed from those affecting outcome of acute infarction. Individual factors were previous history of infarction or of hypertension, tachycardia, cardiac arrest, ventricular arrhythmia, atrial fibrillation, 3rd heart sound, raised venous pressure, and pulmonary crepitations. Multivariate analysis reduced these to 6-previous infarct or hypertension, sinus tachycardia, cardiac arrest, ventricular arrhythmia, and atrial fibrillation. Of those who survived 5 years, approximately half had angina. Two-thirds of the under 60 survivors were at their normal work.

The patient population under observation in this study has been described in the previous paper by Kitchin and Pocock. In brief, 872 patients were admitted directly to the coronary care unit at the Western General Hospital, Edinburgh, during the period April 1966 to April 1969, and of these 508 $(58 \%)$ were judged to have sustained an infarct. This paper is concerned with the prognosis of patients on leaving hospital, so that the 63 deaths in the coronary care unit and the 25 deaths of patients still in hospital after leaving the coronary care unit are excluded. There remains a total of 420 patients with myocardial infarction who left hospital and were followed for periods of 5 to 7 years. This is the population to be examined for long-term prognosis.

\section{Methods}

Ancillary information regarding previous history of disease, signs and symptoms upon admission to the coronary care unit, and other background information (e.g. age, smoking history) were collected on a standard proforma.

Survival follow-up was achieved through either the hospital outpatient clinic or the patient's general practitioner, except for 20 patients who had left the district whose survival was established by the Registrar General's department. A total of 151 deaths was reported. For the patients who survived 5 years, a standard proforma on the patient's state of Received for publication 13 April 1977 health at that time was completed by the general practitioner. The questions asked concerned the recurrence of myocardial infarction, the presence and severity of angina and breathlessness, diuretic therapy, and occupational status. Since these proformas were collected at fixed 2-yearly dates the exact follow-up time of this information varied from 4 to 6 years. Seventy-eight per cent of proformas were completed satisfactorily by the general practitioner and for the remainder a simplified proforma was sent directly to the patient's home. There remained 23 who survived for 5 years $(8 \%)$ for whom this information was unobtainable, and a small number of others with only partial information.

\section{Results}

OVERALL SURVIVAL

Fig. 1 shows the survival curve for all 420 patients who left hospital. Since patients were followed for varying periods ( 5 to 7 years) the life-table method (Cutler and Ederer, 1958) has been applied in all the survival plots presented in this paper. Fig. 1 also shows the survival experience of myocardial infarcts described in 4 previous studies, and it can be seen that the experience in this study is broadly similar. One hundred and twenty-five patients $(30 \%)$ died within 5 years and an estimated 40 per cent died within 7 years.

The death rate was fairly constant during the first $2 \frac{1}{2}$ years at an average of 8.6 per cent per 
Table 1 Long-term survival and patient characteristics

\begin{tabular}{|c|c|c|c|}
\hline Characteristic & Level & $\begin{array}{l}\text { No. of } \\
\text { patients }\end{array}$ & $\begin{array}{l}\text { No. }(\%) \text { dead } \\
\text { within } 5 \\
\text { years }\end{array}$ \\
\hline Age (y) & $\left(\begin{array}{l}<40 \\
40-49 \\
50-59 \\
60-69 \\
70+\end{array}\right.$ & $\begin{array}{r}20 \\
76 \\
165 \\
145 \\
14\end{array}$ & $\begin{array}{r}4(20 \%) \\
18(24 \%) \\
52(32 \%) \\
43(30 \%) \\
8(57 \%)\end{array}$ \\
\hline $\begin{array}{l}\text { Previous history } \\
\text { Angina }\end{array}$ & $\begin{array}{l}\text { Yes } \\
\text { No }\end{array}$ & $\begin{array}{l}185 \\
235\end{array}$ & $\begin{array}{l}64(35 \%) \\
61(26 \%)\end{array}$ \\
\hline $\begin{array}{l}\text { Preinfarction crescendo } \\
\text { angina }\end{array}$ & $\begin{array}{l}\text { Yes } \\
\text { No }\end{array}$ & $\begin{array}{l}157 \\
263\end{array}$ & $\begin{array}{l}42(27 \%) \\
83(32 \%)\end{array}$ \\
\hline Myocardial infarction & $\begin{array}{l}\text { Yes } \\
\text { No }\end{array}$ & $\begin{array}{l}104 \\
316\end{array}$ & $\begin{array}{l}46(44 \%)^{\star \star \star} \\
79(25 \%)\end{array}$ \\
\hline Hypertension & $\begin{array}{l}\text { Yes } \\
\text { No } \\
\text { Unknown }\end{array}$ & $\begin{array}{r}47 \\
371 \\
2\end{array}$ & $\begin{array}{l}23(49 \%)^{\star \star} \\
101(27 \%)\end{array}$ \\
\hline $\begin{array}{l}\text { Family history of } \\
\text { myocardial infarction }\end{array}$ & $\begin{array}{l}\text { Yes } \\
\text { No } \\
\text { Unknown }\end{array}$ & $\begin{array}{r}124 \\
271 \\
25\end{array}$ & $\begin{array}{l}43(35 \%) \\
72(27 \%)\end{array}$ \\
\hline \multicolumn{4}{|l|}{$\begin{array}{l}\text { Electrocardiographic } \\
\text { abnormality }\end{array}$} \\
\hline Position & $\begin{array}{l}\text { Anterior } \\
\text { Inferior } \\
\text { None/ } \\
\text { Unknown }\end{array}$ & $\begin{array}{r}213 \\
197 \\
10\end{array}$ & $\begin{array}{l}66(31 \%) \\
54(27 \%)\end{array}$ \\
\hline$Q$ wave & $\begin{array}{l}\text { Yes } \\
\text { No } \\
\text { Unknown }\end{array}$ & $\begin{array}{r}292 \\
121 \\
7\end{array}$ & $\begin{array}{l}92(32 \%) \\
31(26 \%)\end{array}$ \\
\hline AST enzyme rise & $\left(\begin{array}{l}<40 \\
40-100 \\
>100 \\
\text { Unknown }\end{array}\right.$ & $\begin{array}{r}115 \\
156 \\
125 \\
24\end{array}$ & $\begin{array}{l}30(26 \%) \\
48(31 \%) \\
39(31 \%)\end{array}$ \\
\hline $\begin{array}{l}\text { Lowest systolic blood } \\
\text { pressure }\end{array}$ & $\left\{\begin{array}{l}\geqslant 100 \\
<100\end{array}\right.$ & $\begin{array}{l}212 \\
208\end{array}$ & $\begin{array}{l}66(31 \%) \\
59(28 \%)\end{array}$ \\
\hline Highest pulse rate & $\left\{\begin{array}{l}<100 \\
\geqslant 100\end{array}\right.$ & $\begin{array}{l}269 \\
151\end{array}$ & $\begin{array}{l}55(20 \%)^{\star \star \star} \\
70(46 \%)\end{array}$ \\
\hline Cardiac arrest & Yes & $\begin{array}{r}16 \\
404\end{array}$ & $\begin{array}{l}10(63 \%)^{\star \star} \\
115(28 \%)\end{array}$ \\
\hline \multicolumn{4}{|l|}{ Arrhythmias } \\
\hline Bradyarrhythmias & $\begin{array}{l}\text { Yes } \\
\text { No }\end{array}$ & $\begin{array}{r}30 \\
390\end{array}$ & $\begin{array}{r}8(27 \%) \\
117(30 \%)\end{array}$ \\
\hline Ventricular arrhythmias & $\begin{array}{l}\text { Yes } \\
\text { No }\end{array}$ & $\begin{array}{r}68 \\
352\end{array}$ & $\begin{array}{l}32(47 \%)^{\star \star} \\
93(26 \%)\end{array}$ \\
\hline Atrial fibrillation & $\begin{array}{l}\text { Yes } \\
\text { No }\end{array}$ & $\begin{array}{r}21 \\
399\end{array}$ & $\begin{array}{l}14(67 \%)^{\star \star \star} \\
111(28 \%)\end{array}$ \\
\hline $\begin{array}{l}\text { Supraventricular arrhy- } \\
\text { thmias (including atrial } \\
\text { fibrillation) }\end{array}$ & $\begin{array}{l}\text { Yes } \\
\text { No }\end{array}$ & $\begin{array}{r}31 \\
389\end{array}$ & $\begin{array}{r}14(45 \%) \\
111(29 \%)\end{array}$ \\
\hline Third or fourth heart sound & $\left\{\begin{array}{l}\text { Yes } \\
\text { No } \\
\text { Unknown }\end{array}\right.$ & $\begin{array}{r}136 \\
280 \\
4\end{array}$ & $\begin{array}{l}49(36 \%)^{\star} \\
73(26 \%)\end{array}$ \\
\hline Mitral systolic murmur & $\left\{\begin{array}{l}\text { Yes } \\
\text { No } \\
\text { Unknown }\end{array}\right.$ & $\begin{array}{r}41 \\
375 \\
4\end{array}$ & $\begin{array}{r}17(41 \%) \\
105(28 \%)\end{array}$ \\
\hline $\begin{array}{l}\text { Raised jugular venous } \\
\text { pressure }\end{array}$ & $\left\{\begin{array}{l}\text { Yes } \\
\text { No } \\
\text { Unknown }\end{array}\right.$ & $\begin{array}{r}149 \\
268 \\
3\end{array}$ & $\begin{array}{l}55(37 \%)^{\star} \\
67(25 \%)\end{array}$ \\
\hline Pulmonary crepitations & $\begin{array}{l}\text { Yes } \\
\text { No } \\
\text { Unknown }\end{array}$ & $\begin{array}{r}192 \\
224 \\
4\end{array}$ & $\begin{array}{l}68(35 \%)^{\star \star} \\
53(24 \%)\end{array}$ \\
\hline All patients & & 420 & $125(30 \%)$ \\
\hline
\end{tabular}

annum which is significantly higher than the average 5.5 per cent per annum during the next $2 \frac{1}{2}$ years $(P<0.05)$. This suggests that prognosis improves somewhat once the patient has survived the first $2 \frac{1}{2}$ years after an infarct.

For those dying within 5 years the primary causes of death were: myocardial infarct (78), other cardiovascular diseases (11), cancer (3), other causes (4), and not known (29).

\section{LONG-TERM SURVIVAL AND}

PATIENT CHARACTERISTICS

There were several characteristics recorded about each patient after admission to the coronary care unit. In order to examine which characteristics are associated with long-term survival, Table 1 shows the percentage dead within 5 years for patients classified by each characteristic.

The following characteristics were associated with a significantly poorer survival record after 5 years: previous history of myocardial infarction or hypertension, highest pulse rate $\geqslant 100$ ( 2 or more consecutive 4-hourly recordings), cardiac arrest, ventricular arrhythmia, atrial fibrillation, third or fourth heart sound, raised jugular venous pressure, and pulmonary crepitations. In addition 4 other characteristics (namely age, previous angina, family history, and mitral systolic murmur) may possibly have some impact on long-term survival, though their associations were not quite formally significant.

\section{A PROGNOSTIC INDICATOR FOR SURVIVAL}

The results presented in Table 1 give some idea as to the many factors which influence the patient's survival after leaving hospital. However, the scope of this information is limited by the fact that each factor was considered separately so that the overall combined impact of these factors could not be properly assessed. Therefore, in order to obtain a more accurate prognosis for any individual patient, with his multitude of potentially relevant characteristics, one must consider a multivariate statistical analysis of survival.

Thus, when all the characteristics listed in Table 1 are considered collectively, it turns out that only 6 of them significantly influence a patient's chances of surviving 5 years. These 6 prognostic factors are previous myocardial infarct, previous hypertension, pulse rate $\geqslant 100$, cardiac arrest, ventricular arrhythmia, and atrial fibrillation. This result has been obtained using the maximum likelihood solution of a linear-logistic model for the probability of surviving 5 years (see Cox, 1970) and leads to the following prognostic indicator. 
Let $\mathbf{P}$ be the probability of a patient surviving 5 years. Then

$$
\begin{aligned}
\ln \frac{P}{(1-P)}= & +1.842 \\
& -0.846 \text { If previous myocardial in- } \\
& -0.998 \text { If previous hypertension } \\
& -0.903 \text { If highest pulse rate } \geqslant 100 \\
& -1.215 \text { If cardiac arrest } \\
& -0.630 \text { If ventricular arrhythmia } \\
& -1.353 \text { If atrial fibrillation }
\end{aligned}
$$

where $\ln -$ is the natural logarithm of the odds (1-P)

of surviving 5 years. For example, if a patient has none of these 6 characteristics then $\ln \frac{P}{(1-P)}=1.842$

$$
\text { (1-P) }
$$

and $P$, the probability of surviving 5 years $=0.86$. If a patient has a previous infarct and highest pulse rate $\geqslant 100$ but none of the other characteristics then

$$
\ln \frac{P}{(1-P)}=+1.842-0.846-0.903=+0.093 \text { and }
$$

$\mathbf{P}=\mathbf{0} \cdot 52$. Similarly, provided one knows which of these 6 characteristics are present for a patient, one can then predict his chances of surviving 5 years.

The accuracy of this prognostic indicator has been thoroughly tested using a variety of statistical procedures and the authors have concluded that it is the best predictor that could be derived from the experience of the 420 patients analysed. Of course, it is based on a particular coronary care unit and, therefore, some degree of caution would be advisable in applying the predictor to any other population except as a general guideline.

It is evident that cardiac arrest and atrial fibrillation make the greatest contribution to the prognostic indicator whereas ventricular arrhythmia, with the smallest coefficient in the formula above, makes the least contribution out of the 6 patient characteristics. However, all the 6 coefficients are of a similar order of magnitude so that without any great loss of information one could express the survival prognosis of a patient simply by the number of these characteristics he has experienced. For instance, Fig. 2 shows the survival curves for patients categorised according to this number of unfavourable characteristics. Evidently, there is considerable discrimination between the 4 groups of patients throughout the 7-year period of follow-up. In particular, the 5-year percentages surviving are $86,72,52$, and 27 , for those with none, 1,2 , and 3 or more characteristics, respectively.
HEALTH AND EMPLOYMENT STATUS AFTER 5 YEARS

The results now described were collected on a standard proforma mostly from the patient's general practitioner at some time between 4 and 6 years after leaving hospital (see methods above for further details). Table 2 shows the replies obtained for the 295 5-year survivors. These results from a survivor population have the obvious limitation that most of the more severely affected will have already died, but there are one or two interesting features worthy of comment.

At 5 years 7 per cent of survivors reported probable and another 9 per cent possible recurrences of infarction. Of 57 patients who had given a past history of infarction, 30 per cent had probable or possible recurrence.

Angina was reported after 5 years in 121 (45\%) of survivors. Of the 115 with angina before the

\begin{tabular}{|c|c|c|}
\hline & & $\begin{array}{l}\text { No. of patients } \\
\text { (\% ignoring } \\
\text { unknowns) }\end{array}$ \\
\hline $\begin{array}{l}\text { Recurrence of myocardial } \\
\text { infarct within the 5-year } \\
\text { period }\end{array}$ & $\begin{array}{l}\text { No } \\
\text { Possible } \\
\text { Probable } \\
\text { Unknown }\end{array}$ & $\begin{array}{l}224(84 \%) \\
24(9 \%) \\
20(7 \%) \\
27\end{array}$ \\
\hline Angina now present & $\begin{array}{l}\text { None } \\
\text { Mild } \\
\text { Moderate } \\
\text { Severe } \\
\text { Unknown }\end{array}$ & $\begin{array}{l}150(53 \%) \\
70(25 \%) \\
36(13 \%) \\
15(5 \%) \\
24\end{array}$ \\
\hline Breathlessness now present & $\begin{array}{l}\text { None } \\
\text { Mild } \\
\text { Moderate } \\
\text { Severe } \\
\text { Unknown }\end{array}$ & $\begin{array}{l}141(53 \%) \\
68(26 \%) \\
42(16 \%) \\
14(5 \%) \\
30\end{array}$ \\
\hline $\begin{array}{l}\text { Currently receiving diuretic } \\
\text { therapy }\end{array}$ & $\begin{array}{l}\text { No } \\
\text { Yes } \\
\text { Unknown }\end{array}$ & $\begin{array}{l}232(86 \%) \\
38(14 \%) \\
25\end{array}$ \\
\hline Current employment status & $\begin{array}{l}\text { Returned to } \\
\text { normal work } \\
\text { Lighter job } \\
\text { Can't find job } \\
\text { Unable to work } \\
\text { Unknown or } \\
\text { inapplicable }\end{array}$ & $\begin{array}{c}102(65 \%) \\
31(20 \%) \\
11(7 \%) \\
14(9 \%) \\
137\end{array}$ \\
\hline
\end{tabular}
infarct 5 years before, $73(63 \%)$ still had angina, whereas of the 156 without previous angina only $48(31 \%)$ were now affected $(P<0.001)$.

Shortness of breath was reported by 47 per cent of the 5-year survivors. This increased to 62 per cent if they had had heart failure in the form of pulmonary crepitations at the time of infarction as

Table 2 Health and employment status for 5-year survivors (295 patients) 
compared with 39 per cent of those who did not $(P<0.001)$.

The question about employment status was considered applicable only to men under age 60 . Those under age 50 had fared somewhat better than those in their 50's with 75 per cent at their normal work compared with 57 per cent $(P<0.05)$. There was also a strong relation between employment status and presence of angina since 72 per cent of those without angina were at their normal work compared with only 45 per cent of those with moderate or severe angina $(P<0.01)$.

\section{Discussion}

The 5-year survival rate in the present series for male patients who survived to leave hospital after acute myocardial infarction was $\mathbf{7 0}$ per cent and for patients with first infarcts it was 75 per cent. Fig. 1 shows a comparison of these results with the results of 4 other studies, the Health Insurance Plan of New York (Frank et al., 1973) who found a survival rate of 81 per cent at $4 \frac{1}{2}$ years for patients with first infarcts, the Oslo Diet Study of Leren (1970), the series of Zukel et al. (1969) relating to army personnel in the war, and the Mayo Clinic series of Juergens et al. (1960). The study of Honey and Truelove (1957) in Oxford patients showed a 61 per cent survival rate at 5 years and Pell and D'Alonzo (1964) reported a 74 per cent survival rate at 5 years in male employees surviving a first

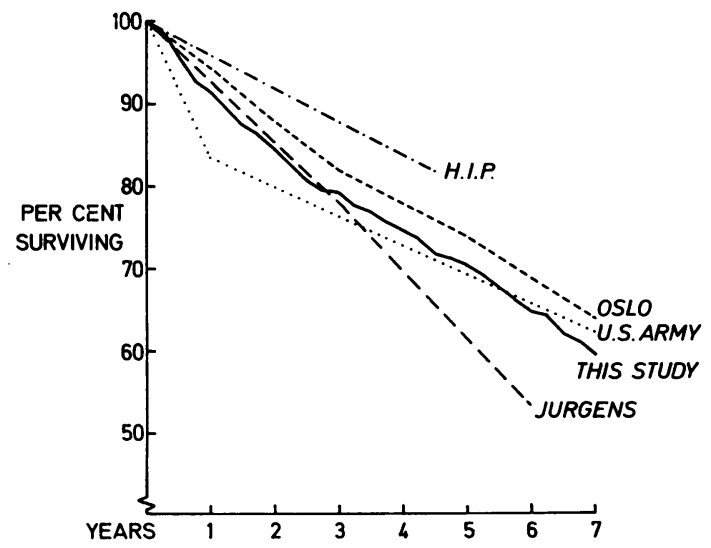

Fig. 1 Long-term survival after leaving hospital for 420 patients, compared with 4 previous studies. Health Insurance Programme (H.I.P.) (Frank et al., 1973); Oslo Diet-Heart Study (Leren, 1970); Zukel et al. (1969); fuergens et al. (1960). infarct. The findings of the present study are, therefore, intermediate in position. The Health Insurance Programme Study was a prospective one and therefore likely to include milder cases. The same applies to Zukel's study of army personnel who were younger and, in some cases, asymptomatic. Here, however, a high mortality was reported during the first year.

Several of these studies have identified factors associated with a poor long-term prognosis. The Health Insurance Programme Study identified a previous history of hypertension and of angina pectoris as unfavourable factors. Pell and D'Alonzo found that increasing age and a previous history of hypertension were unfavourable. Leren found that a previous history of myocardial infarction or of hypertension worsened the long-term prognosis. The Veterans' Administration Study of Beard et al. (1960) who found a 69 per cent survival at 5 years after first infarction, identified the factors of age, previous hypertension or angina, cardiac failure at the time of infarction, serious arrhythmia at the time of infarction, and high fever after myocardial

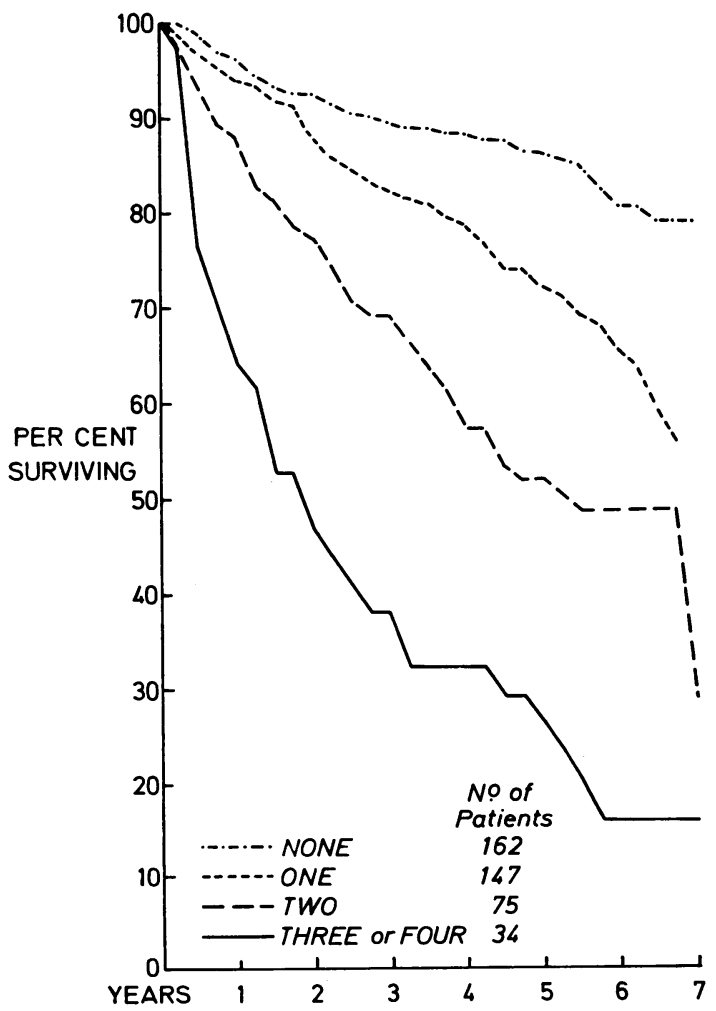

Fig. 2 Long-term survival related to presence or absence of 6 unfavourable characteristics. 
infarction as unfavourable prognostic factors. Norris and his co-workers (1974) have studied survival over a 3-to-6-year period after myocardial infarction. They found hypertension to be adverse, and confirmed the adverse effect of increasing age and previous history of infarction and of the occurrence of signs of cardiac failure at the time of infarction. Anterior transmural infarcts carried a slightly worse prognosis than inferior (Norris and Mercer, 1973) and the occurrence of ventricular arrhythmias during the acute infarct also carried a bad prognosis though the authors argued that this factor did not stand on its own but merely reflected the presence of other adverse features.

In the present data a previous history of myocardial infarction or hypertension, sinus tachycardia, atrial fibrillation, third heart sound, raised venous pressure, pulmonary crepitations, ventricular arrhythmia, and occurrence of cardiac arrest were all found to be individual factors associated with poorer prognosis. It is clear that many of these factors, which have been individually identified, are associated with one another, as for example various manifestations of left ventricular failure, previous myocardial damage or deranged myocardial metabolism or electrophysiology. An attempt has, therefore, been made by multifactorial analysis to pick out factors which exert an independent adverse effect on long-term prognosis. Of the 6 factors identified in the present data, i.e. previous myocardial infarction or hypertension, sinus tachycardia or atrial fibrillation, ventricular arrhythmia or cardiac arrest occurring during the course of the acute infarction, only atrial fibrillation has not been mentioned in other series. Though it occurred in a relatively small number of cases it was associated with a very poor 5 -year survival. Persistent sinus tachycardia after infarction was found by Norris and Mercer (1973) to be an unfavourable prognostic sign while previous myocardial infarction and hypertension are recognised in nearly all series as being unfavourable. Supraventricular arrhythmias and bradyarrhythmias were not adverse prognostic factors unlike ventricular arrhythmias, and here again the data are in agreement with the findings of Norris et al. Cardiac arrest, which in this case means ventricular fibrillation, was associated with a survival rate of 63 per cent at 3 years and 35 per cent at 5 years, conspicuously worse than for the series as a whole, while Norris and Mercer (1973) reported a 3-year survival of 58 per cent.

The two factors of increasing age and a previous history of angina pectoris were found to be of borderline significance in the present study where both the Health Insurance Programme Study of Frank et al. (1973) and the series of Norris et al. found them to be significant factors. The data also did not confirm Norris's finding of a significantly worse prognosis in anterior as opposed to inferior infarcts and transmural as opposed to intramural infarcts.

There is thus a large amount of agreement in published series regarding most of the factors which indicate a poor 5-year survival after myocardial infarction. These differ both from the risk factors associated with the development of signs of coronary disease and the factors relating to the outcome of an acute myocardial infarction. The present study has attempted to identify the most important of these factors and secondly (Fig. 2) to show how closely the long-term prognosis is linked to the number of these 6 factors identified as present when the patient leaves hospital after recovery from acute infarction.

\section{References}

Beard, O. W., Hipp, H. R., Robins, M., Taylor. J. S., Ebert, R. V., and Beran, L. G. (1960). Initial myocardial infarction among 503 veterans. American fournal of Medicine, 28, 871883.

Cox, D. R. (1970). The Analysis of Binary Data, pp. 87-91. Methuen, London.

Cutler, S. J., and Ederer, F. (1958). Maximum utilization of the life table method in analyzing survival. Fournal of Chronic Diseases, 8, 699-712.

Frank, C. W., Weinblatt, E., and Shapiro, S. (1973). Angina pectoris in men; prognostic significance of selected medical factors. Circulation, 47, 509-517.

Honey, G. E., and Truelove, S. C. (1957). Prognostic factors in myocardial infarction. Lancet, 1, 1155-1161.

Juergens, J. L., Edwards, J. E., Achor, R. W. P., and Burchell, H. B. (1960). Prognosis of patients surviving first clinically diagnosed myocardial infarction. Archives of Internal Medicine, 105, 444-450.

Leren, P. (1970). The Oslo diet-heart study. Circulation, 42, 935-942.

Norris, R. M., Caughey, D. E., Mercer, C. J., and Scott, P. J. (1974). Prognosis after myocardial infarction. Six year follow-up. British Heart fournal, 36, 786-790.

Norris, R. M., and Mercer, C. J. (1973). Long-term prognosis following treatment in a coronary care unit. Australian and New Zealand fournal of Medicine, 3, 31-37.

Pell, S., and D'Alonzo, C. A. (1964). Immediate mortality and five-year survival of employed men with a first myocardial infarction. New England fournal of Medicine, 270, 915-922.

Zukel, W. J., Cohen, B. M., Mattingley, T. W., and Hrubec, Z. (1969). Survival following first diagnosis of coronary heart disease. American Heart fournal, 78, 159-170.

Requests for reprints to Dr. A. H. Kitchin, Department of Medicine, Western General Hospital, Edinburgh EH4 2XU. 